\title{
RADIONUCLIDE LEACHING FROM RESIDUAL SOLIDS REMAINING AFTER ACID DISSOLUTION OF K EAST AREA SLUDGE COMPOSITE
}

CH Delegard

DE Rinehart

CD Carlson

CZ Soderquist

SK Fadeff

September 11, 1998

Prepared for

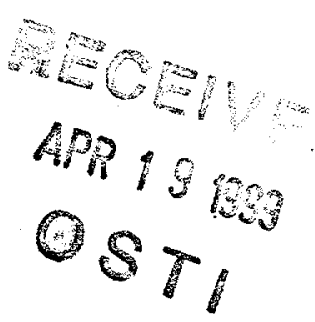

Numatec Hanford Corporation

Work Supported by the U.S. Department of Energy under Contract DE-AC06-76RLO 1830

Pacific Northwest National Laboratory

Richland, Washington 99352 


\title{
DISCLAIMER
}

This report was prepared as an account of work sponsored by an agency of the United States Government. Neither the United States Government nor any agency thereof, nor Battelle Memorial Institute, nor any of their employees, makes any warranty, express or implied, or assumes any legal liability or responsibility for the accuracy, completeness, or usefulness of any information, apparatus, product, or process disclosed, or represents that its use would not infringe privately owned rights. Reference herein to any specific commercial product, process, or service by trade name, trademark, manufacturer, or otherwise does not necessarily constitute or imply its endorsement, recommendation, or favoring by the United States Government or any agency thereof, or Battelle Memorial Institute. The views and opinions of authors expressed herein do not necessarily state or reflect those of the United States Government or any agency thereof.

\author{
PACIFIC NORTHWEST NATIONAL LABORATORY \\ operated by \\ BATTELLE \\ for the \\ UNITED STATES DEPARTMENT OF ENERGY \\ under Contract DE-AC06-76RLO 1830
}

Printed in the United States of America

Available to DOE and DOE contractors from the

Office of Scientific and Technical Information, P.O. Box 62, Oak Ridge, TN 37831;

prices available from (615) 576-8401.

Avallable to the public from the National Technical Information Service, U.S. Department of Commerce, 5285 Port Royal Rd., Springfield, VA 22161

This document was printed on recycled paper. 


\section{DISCLAIMER}

Portions of this document may be illegible in electronic image products. Images are produced from the best available original document. 


\section{Summary and Conclusions}

Laboratory tests were performed to examine the efficacy of various leach treatments for decontaminating dissolver residual solids (KEACRESID1) produced during a 24-hour dissolution of K East Basin floor and Weasel Pit sludge composite in boiling $6 \mathrm{M} \mathrm{HNO}_{3}$. The scope of this testing has been described in Section 4.5 of "Testing Strategy to Support the Development of K Basin Sludge Treatment Process". (Flament 1998). Radionuclides sorbed or associated with the residual solids generated in the K Basin sludge treatment process can restrict disposal of this solid to the Environmental Restoration Disposal Facility (ERDF).

The starting dissolver residual solid for this testing, KEACRESID1, is a visibly heterogeneous material. This material contains radionuclides at concentrations above the ERDF Waste Acceptance Criteria for transuranics (TRU) by about a factor of 3 , for ${ }^{239} \mathrm{Pu}$ by a factor of 10 , and for ${ }^{241} \mathrm{Am}$ by a factor of 1.6. It meets (is below) the ERDF criterion for ${ }^{137} \mathrm{Cs}$ by a factor of 4 and for uranium by a factor of 10 . Therefore, the radionuclides of greatest interest in this leaching study are first ${ }^{239} \mathrm{Pu}$, and then ${ }^{241} \mathrm{Am}$, ${ }^{137} \mathrm{Cs}$, and uranium.

Based on the recommendations of separate engineering studies, four alternative leach treatment methods were tested. The four candidate leachants are nitric acid solutions of $\mathrm{Ce}$ (IV), $\mathrm{Ag}(\mathrm{II}) /$ persulfate, hydrofluoric acid, and hydrochloric acid. The silver/persulfate leachant was tested at room temperature $\left(24^{\circ} \mathrm{C}\right)$ and the other leachants at $90^{\circ} \mathrm{C}$. All leach tests were performed in duplicate for 4 hours' contact time using approximately $24 \mathrm{~mL}$ of leachant per gram of residual solids $(4.00 \mathrm{~mL}$ of leachant with roughly 0.16 grams of solid).

The ${ }^{137} \mathrm{Cs}$ concentrations in the solids, already below the ERDF limit at about $3.7 \mu \mathrm{Ci} / \mathrm{g}$ in the starting material, decreased by a factor of 1.2 to 4 for all tests. Uranium concentrations in the leached solids ranged from about 20 to $70 \mu \mathrm{g} / \mathrm{mL}$ (assuming a solids density of $2.0 \mathrm{~g} / \mathrm{mL}$ ). These concentrations are about 40 - to 130 -fold below the ERDF limit of $2,600 \mu \mathrm{g} / \mathrm{mL}$.

Of the four leachants tested, the $6 \mathrm{M} \mathrm{HNO}_{3} / 0.3 \mathrm{M} \mathrm{HF}$ leachant clearly gave the best decontamination from TRU, plutonium, americium, and uranium. Under the stated conditions, $89 \%$ of the plutonium, $95 \%$ of the americium, $90 \%$ of the TRU, and $91 \%$ of the uranium reported to solution. The leached solids are about $3 / 2$ the ERDF criterion for ${ }^{239} \mathrm{Pu}$, about $1 / 10$ the ERDF criterion for ${ }^{241} \mathrm{Am}$, and $1 / 2$ the ERDF criterion for TRU. The ${ }^{239} \mathrm{Pu}$ concentration in the nitric/hydrofluoric acid-leached residue was about 47 $\mathrm{nCi} / \mathrm{mL}$ to give a decontamination factor of about 8 . The ${ }^{241} \mathrm{Am}$ concentration decreased about 16 -fold by nitric/hydrofluoric acid treatment. The decontamination from Am is strikingly superior to that attained by any other leachant. 


\section{Contents}

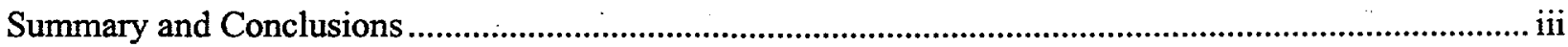

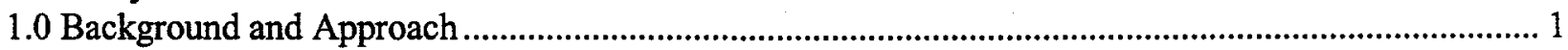

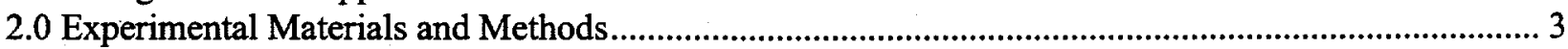

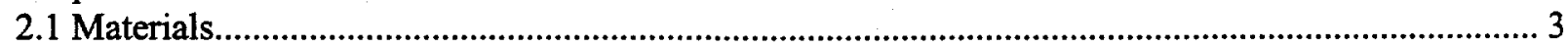

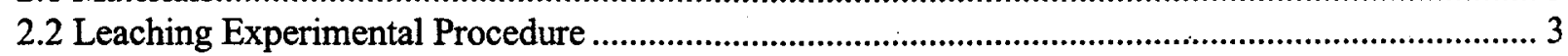

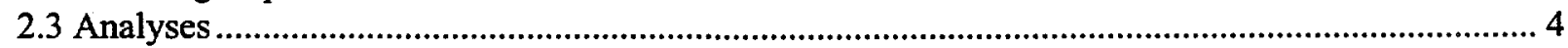

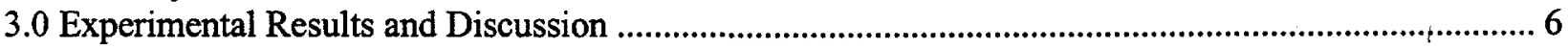

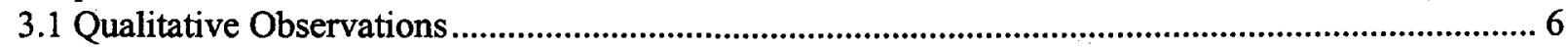

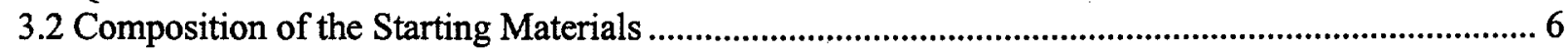

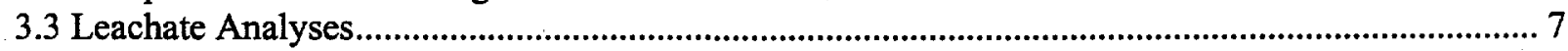

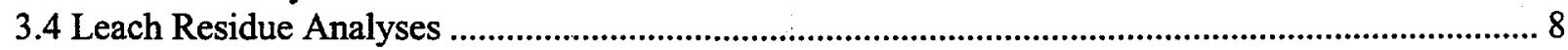

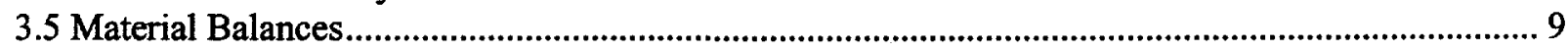

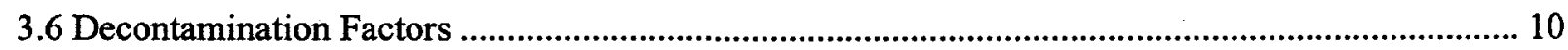

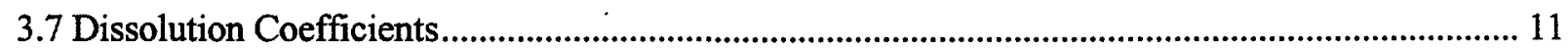

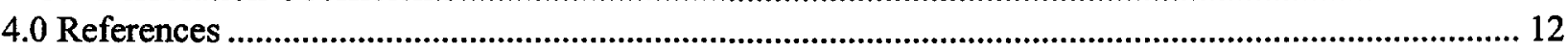

\section{Tables}

Table 1. Leachants and Material Weights in Leach Testing ............................................................. 4

Table 2. Radiochemical Concentrations and Quantities in the Starting Materials ................................... 6

Table 3. Radiochemical Concentrations in Combined Test Solutions, Leachates, and Rinses.................. 7

Table 4. Radiochemical Concentrations in Test Residues ................................................................ 8

Table 5. Leach Testing Material Balance for ${ }^{137} \mathrm{Cs}$.......................................................................... 9

Table 6. Leach Testing Material Balance for Uranium ................................................................... 9

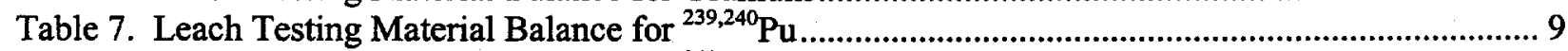

Table 8. Leach Testing Material Balance for ${ }^{241} \mathrm{Am}$......................................................................... 10

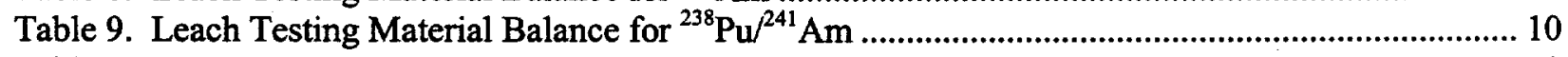

Table 10. Leach Testing Material Balance for Total Alpha ............................................................... 10

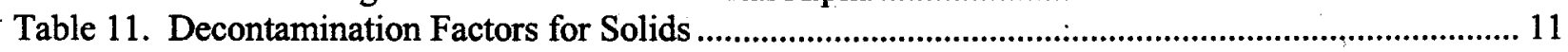

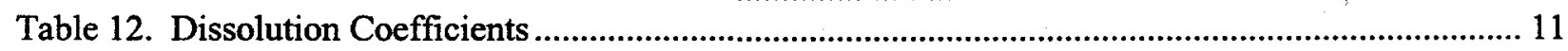




\subsection{Background and Approach}

Leach tests were performed on the residual solids created by dissolving a $\mathrm{K}$ East Basin floor and Weasel Pit sludge composite in $6 \underline{\mathrm{M} \mathrm{HNO}} \mathrm{HN}_{3}$ for 24 hours at boiling temperatures. Four candidate leachants were tested. Background information, the experiments performed, and the experimental results are presented in this report.

Solids to be delivered to the Environmental Restoration Disposal Facility (ERDF) must meet Waste Acceptance Criteria (WAC) for radionuclide concentration (ERDF 1998). The radionuclides most likely limiting the ERDF acceptance of $\mathrm{K}$ Basin residual solids are ${ }^{137} \mathrm{Cs}\left(32 \mathrm{Ci} / \mathrm{m}^{3}\right.$ or $\left.32 \mu \mathrm{Ci} / \mathrm{mL}\right)$ and the transuranics (TRU; $100 \mathrm{nCi} / \mathrm{g}$ ). The TRU isotopes have individual limits: ${ }^{241} \mathrm{Am}, 0.05 \mathrm{Ci} / \mathrm{m}^{3}(50$ $\mathrm{nCi} / \mathrm{mL}) ;{ }^{238} \mathrm{Pu}, 1.5 \mathrm{Ci} / \mathrm{m}^{3}(1,500 \mathrm{nCi} / \mathrm{mL})$; and ${ }^{239} \mathrm{Pu}$ and ${ }^{240} \mathrm{Pu}, 0.029 \mathrm{Ci} / \mathrm{m}^{3}(29 \mathrm{nCi} / \mathrm{mL})$ each. Because ${ }^{240} \mathrm{Pu}$ represents about $1 / 3$ of the ${ }^{239,240} \mathrm{Pu}$ activity in $\mathrm{K}$ Basin materials, and the ERDF activity concentration limits for ${ }^{239} \mathrm{Pu}$ and ${ }^{240} \mathrm{Pu}$ are identical, the ${ }^{239} \mathrm{Pu}$ limit is the more restrictive for ERDF disposal acceptance. The effective uranium limit for disposal to ERDF, $0.0026 \mathrm{~g} \mathrm{U} / \mathrm{mL}^{1}$, has the potential to restrict the disposal of certain $\mathrm{K}$ Basin residual solids.

Residual solids from acid dissolution of several $\mathrm{K}$ Basin sludge samples and composites have been characterized. The ${ }^{137} \mathrm{Cs}$ concentrations range from 180 to $550 \mu \mathrm{Ci} / \mathrm{mL}$ in residual solids from $\mathrm{K}$ East canister sludge sample $96-08$ and from 90 to $122 \mu \mathrm{Ci} / \mathrm{mL}$ in residual solids from Weasel Pit sample T-20. The respective TRU concentrations are 7,500-13,500 and $460-780 \mathrm{nCi} / \mathrm{g}$ with plutonium comprising about $2 / 3$ and americium $1 / 3$ of the TRU activities. Uranium concentrations in the 96-08 residual solids range from 0.025 to $0.061 \mathrm{~g} \mathrm{U} / \mathrm{mL}$ and from 0.0096 to $0.013 \mathrm{~g} \mathrm{U} / \mathrm{mL}$ in T-20 (Schmidt et al. 1999; the volumetric concentrations are derived assuming a solids density of $2.66 \mathrm{~g} / \mathrm{mL}$ ). Radiochemical analytical data show acid dissolution residual solids from $K$ East floor and Weasel Pit composite (designated KEACOMP) range from 5 to $65 \mu \mathrm{Ci}{ }^{137} \mathrm{Cs} / \mathrm{g}$. The ${ }^{239,240} \mathrm{Pu}$ and ${ }^{241} \mathrm{Am}$ concentrations in the same residual solids range from 130 to $3,000 \mathrm{nCi} / \mathrm{g}$ and 80 to $600 \mathrm{nCi} / \mathrm{g}$, respectively.

The radionuclide contamination in residual solids seems to be most severe for plutonium (i.e., plutonium concentrations are farthest from the relevant acceptance criterion). Therefore, chemical dissolution methods should target plutonium and secondarily be effective for the other key radioelements, ${ }^{241} \mathrm{Am}$, ${ }^{137} \mathrm{Cs}$, and uranium. Analyses by inductively coupled plasma (ICP) spectrometry show the major chemical components of the residual solids to be silicon and iron. Therefore, to dissolve plutonium and the other radionuclides, leachants must attack plutonium phases such as $\mathrm{PuO}_{2}$ or the silica and iron (hydr)oxide in which the plutonium may be trapped.

An engineering study was performed to identify chemical agents to leach radioactive components, particularly plutonium, from $\mathrm{K}$ Basins sludge dissolver residual solids (Bechtold 1998). Five candidate leachants were identified in that study: $\mathrm{Ce}(\mathrm{IV})$, persulfate $\left(\mathrm{S}_{2} \mathrm{O}_{8}{ }^{2-}\right)$ with $\mathrm{Ag}(\mathrm{II})$ catalyst, hydrofluoric acid (HF), Citrox (a combination of citric and oxalic acids), and hydrochloric acid ( $\mathrm{HCl})$. The Citrox process was not selected for the initial studies because its target residue, iron (hydr)oxides, are more readily leached in hydrochloric acid.

\footnotetext{
${ }^{1}$ The ERDF WAC limit for ${ }^{238} \mathrm{U}$ and its daughters is $0.012 \mathrm{Ci} / \mathrm{m}^{3}$. With 8 alpha and 6 beta decays in the ${ }^{238} \mathrm{U}$ decay chain and a specific activity of $3.36 \times 10^{-7} \mathrm{Ci}^{238} \mathrm{U} / \mathrm{g}$, the specific activity of the ${ }^{238} \mathrm{U}$ chain is $4.7 \times 10^{-6} \mathrm{Ci} / \mathrm{g}$. The ERDF limit for ${ }^{238} \mathrm{U}$ thus is $0.00256 \mathrm{~g}^{238} \mathrm{U} / \mathrm{mL}$. The ERDF limit for ${ }^{235} \mathrm{U}$ (daughters not included) is $0.0027 \mathrm{Ci} / \mathrm{m}^{3}$ and the specific activity of ${ }^{235} \mathrm{U}$ is $2.16 \times 10^{-6} \mathrm{Ci} / \mathrm{g}$. Thus, the ERDF limit for ${ }^{235} \mathrm{U}$ is $0.0013 \mathrm{~g}{ }^{235} \mathrm{U} / \mathrm{mL}$. The relative limits of the two uranium isotopes, and the nominal $0.7 \%$ enrichment of the $\mathrm{K}$ Basins sludge, mean that ${ }^{238} \mathrm{U}$ concentration limits ERDF disposal. Therefore, the effective uranium limit for disposal to ERDF is $0.0026 \mathrm{~g} \mathrm{U} / \mathrm{mL}$.
} 
The remaining four candidate leachants [Ce(IV), persulfate with Ag(II) catalyst, hydrofluoric acid, and hydrochloric acid] are all in nitric acid $\left(\mathrm{HNO}_{3}\right)$ media. Both $\mathrm{Ce}(\mathrm{IV})$ and persulfate with $\mathrm{Ag}(\mathrm{II})$ are strong oxidants and are targeted at $\mathrm{PuO}_{2}$. They are effective because they convert the chemically stable solid $\mathrm{PuO}_{2}$ to dissolved $\mathrm{PuO}_{2}{ }^{2+}$. However, aside from the slight contribution from the contained nitric acid, neither leachant is expected to be effective in attacking siliceous or ferric residues remaining from prior extensive nitric acid leaching. The $\mathrm{HF}$ should be effective for both $\mathrm{PuO}_{2}$ and siliceous solids because of the strong affinity of the fluoride ion for $\mathrm{Pu}(\mathrm{IV})$ and $\mathrm{Si}$ (IV) to break down the respective oxide phases. The $\mathrm{HCl}$ is targeted at the ferric (hydr)oxides (e.g., goethite, hematite) because of the strong complexing affinity of the chloride ion for $\mathrm{Fe}(\mathrm{III})$. 


\subsection{Experimental Materials and Methods}

All testing and analyses were performed in the Radiochemical Processing Laboratory (RPL). Approved Test Instructions were followed for executing the leach contact tests. The leach contacts were made in open-faced hoods in the RPL.

\subsection{Materials}

Leach tests were performed on the residual solids (designated as KEACRESID1) created by dissolving $\mathrm{K}$ East floor/Weasel Pit sludge composite (KEACOMP) in $6 \mathrm{M} \mathrm{HNO}_{3}$ for 24 hours at boiling temperatures. The KEACRESID1 material is a visibly heterogeneous mixture of white granules in a pale green powder.

Because it was suspected that the white granules might have been Zeolon-900TM (a zeolitic material, composed of the mineral mordenite, used to remove ${ }^{137} \mathrm{Cs}$ from $\mathrm{K}$ Basin waters), X-ray diffraction (XRD) analyses of the separate white granules (KEACRESID3) and the composite material (granules plus pale green powder; KEACRESID1) were performed. The XRD showed no mordenite to be present in either sample. The crystalline material present in both samples was found to be quartz ( $\left.\mathrm{SiO}_{2} ; \mathrm{PDF} 46-1045\right)$ and anorthite (idealized formula $\mathrm{CaAl}_{2} \mathrm{Si}_{2} \mathrm{O}_{8}$; $\mathrm{PDF}$ 41-1486 and PDF 41-1481). This mineral assemblage is similar to that found for a sample of soil taken 200 feet west of the KE Basin roll-up door (XRD scan 980511B). The KEACRESID1 and KEACRESID3 samples differed in that the quartz pattern in the KEACRESID3 material was much lower than that found for the KEACRESID1 composite material. A more complete description of the generation and properties of the KEACRESID1 material is provided in a separate study (Carlson et al. 1998).

Leach solutions were prepared using distilled and deionized (DI) water and reagent-grade chemicals: crystalline ceric ammonium nitrate $\left[\left(\mathrm{NH}_{4}\right)_{2} \mathrm{Ce}\left(\mathrm{NO}_{3}\right)_{6}\right]$, silver nitrate $\left(\mathrm{AgNO}_{3}\right)$, and potassium persulfate $\left(\mathrm{K}_{2} \mathrm{~S}_{2} \mathrm{O}_{8}\right)$; and $15.9 \mathrm{M}$ nitric acid $\left(\mathrm{HNO}_{3}\right), 29 \mathrm{M}$ hydrofluoric acid, and $12.1 \mathrm{M}$ hydrochloric acid solutions. The leachants were $6 \underline{\mathrm{M} \mathrm{HNO}} 3 / 0.4 \underline{\mathrm{M}}\left(\mathrm{NH}_{4}\right)_{2} \mathrm{Ce}\left(\mathrm{NO}_{3}\right)_{6}, 4 \underline{\mathrm{M}} \mathrm{HNO}_{3} / 0.5 \underline{\mathrm{M} \mathrm{K}} \mathrm{S}_{2} \mathrm{O}_{8} / 0.2 \underline{\mathrm{M}}$ $\mathrm{AgNO}_{3}, 6 \underline{\mathrm{M} \mathrm{HNO}} 3 / 0.3 \mathrm{M} \mathrm{HF}$, and $6 \underline{\mathrm{M} \mathrm{HNO}} 3 / 0.3 \underline{\mathrm{M} \mathrm{HCl}}$. A $6 \underline{\mathrm{M}} \mathrm{HNO}_{3}$ solution was used for rinsing. Reagents were prepared quantitatively ( \pm 0.0001 gram) using a Mettler AE 240 balance, calibrated pipets, and volumetric glassware.

The Ce(IV) leach solution was near saturation in ceric salt; separate tests showed the solubility to be less than $0.5 \underline{\mathrm{M}} \mathrm{Ce}(\mathrm{IV})$ in $6 \underline{\mathrm{M}} \mathrm{HNO}_{3}$. The silver/persulfate reagent was prepared only 2 hours before the commencement of leaching to minimize the loss of the reagent caused by its attack on water. This reagent apparently exceeded saturation in $\mathrm{K}_{2} \mathrm{~S}_{2} \mathrm{O}_{8}$ as shown by the presence of white crystalline solids in the prepared leachant. The nitric/hydrofluoric acid solution was prepared and stored in plastic vessels because of its aggressiveness towards glass. All other reagents were prepared and stored in glass vessels.

\subsection{Leaching Experimental Procedure}

The leach testing was performed in duplicate for each of the four leachant test conditions. First, eight $\sim 0.15$-gram aliquots of dissolver residual solids (KEACRESID1) were weighed ( \pm 0.0001 grams) into 2dram glass vials in the RPL shielded analytical laboratory hot cell facility. The aliquots.were wetted with about $1 \mathrm{~mL}$ of DI water to limit the solids dispersability in air, and the aliquots transferred to an open-face hood for the leach testing. Once in the hood, the aliquots were transferred by transfer pipette into tareweighed $15-\mathrm{mL}$ capped polypropylene centrifuge cones. Additional DI water was used to aid in the rinse and transfer from the glass vials. 
Direct aliquot weighing into the plastic centrifuge cones was not done because of radioactive contamination caused by static electricity effects between the dry solids powder and the plastic. Leach tests were not performed in glass because of the glass corrosion caused by HF in the third leachant. Polypropylene cones were selected because separate tests demonstrated that they could withstand, without deformation or obvious chemical attack, 4 hours' contact with $6 \underline{\mathrm{M} \mathrm{HNO}} 3 / 0.4 \underline{\mathrm{M}} \mathrm{Ce}(\mathrm{IV})$ at $100^{\circ} \mathrm{C}$.

Following quantitative transfer of the solids to the plastic centrifuge cones, the cones and contents were centrifuged and the supernatant solution withdrawn by transfer pipette. The solutions from each tube were collected separately in labeled vessels. The total amount of transfer and rinse water was around 2 $\mathrm{mL}$. The cones with wet solids were reweighed and found to contain from 0.2 to $0.4 \mathrm{~mL}$ residual water. This amount of water would dilute the leachant concentration no more than $8 \%$. The wet solids then were contacted with their respective leachants. The leachants, leach temperatures, and the weights of KEACRESID1 used in the eight leach tests are described in Table 1.

Table 1. Leachants and Material Weights in Leach Testing

\begin{tabular}{|c|c|c|c|}
\hline Test & Leachant & Temperature, ${ }^{\circ} \mathrm{C}$ & Mass KEACRESID1, grams \\
\hline ACRES 1 & \multirow[t]{2}{*}{$6 \mathrm{M} \mathrm{HNO}_{3} / 0.4 \mathrm{M} \mathrm{Ce}(\mathrm{IV})$} & \multirow[t]{2}{*}{90} & 0.1475 \\
\hline ACRES 2 & & & 0.1496 \\
\hline ACRES 3 & \multirow{2}{*}{$\begin{array}{c}4 \underline{\mathrm{MNO}} \mathrm{HNO}_{3} / 0.5 \mathrm{M} \mathrm{K}_{2} \mathrm{~S}_{2} \mathrm{O}_{8} \\
0.2 \underline{\mathrm{M} \mathrm{AgNO}_{3}}\end{array}$} & \multirow[t]{2}{*}{24} & 0.1585 \\
\hline ACRES 4 & & & 0.1721 \\
\hline ACRES 5 & \multirow[t]{2}{*}{$6 \underline{\mathrm{M} H N O} \mathrm{HN}_{3} / 0.3 \underline{\mathrm{MFF}}$} & \multirow[t]{2}{*}{90} & 0.1533 \\
\hline ACRES 6 & & & 0.2228 \\
\hline ACRES 7 & \multirow[t]{2}{*}{$6 \mathrm{M} \mathrm{HNO}_{3} / 0.3 \mathrm{M} \mathrm{HCl}$} & \multirow[t]{2}{*}{90} & 0.1502 \\
\hline ACRES 8 & & & 0.1674 \\
\hline
\end{tabular}

All leach contacts were conducted with $4.00 \mathrm{~mL}$ of leachant. The tests with the silver/persulfate leachant (ACRES 3 and 4) took place at ambient hood temperature $\left(24^{\circ} \mathrm{C}\right)$. The tests with the other leachants were conducted at $90^{\circ} \mathrm{C}$ controlled by use of a thermostatted water bath. The duration of all leach contacts was 4 hours. The solids and leachants were agitated intermittently (at the beginning and at $0.5,1,2,3$, and 4 hours) and left in racks with the caps slightly open between agitations to allow offgassing.

After 4 hours' contact, the tubes were tightly capped and centrifuged, and the supernatant solutions removed by transfer pipette. The leachate solutions were combined with the transfer water. Each leached solid then was washed, centrifuged, and decanted four times with $1-\mathrm{mL}$ portions of $6 \mathrm{M} \mathrm{HNO}$ to remove the interstitial leachant. The washes, too, were added to the transfer water and leachate. The washed solids were dried in a $70^{\circ} \mathrm{C}$ oven for about 18 hours. The composited transfer water, leachate, and rinses for each test and the respective leached and dried solids were submitted for radiochemical analyses.

\subsection{Analyses}

The radiochemical analyses were performed in the RPL analytical laboratory using established procedures.

The residual solids remaining from the eight leach tests were transferred quantitatively from their centrifuge cones, reweighed, and digested by caustic fusion in molten potassium hydroxide (KOH) followed by acid dissolution. The digestates were analyzed for uranium concentration by laser fluorimetry; ${ }^{137} \mathrm{Cs}$ and ${ }^{241} \mathrm{Am}$ concentrations by gamma energy analysis (GEA); and total alpha, ${ }^{239,240} \mathrm{Pu}$, and ${ }^{238} \mathrm{Pu}{ }^{241} \mathrm{Am}$ concentrations by alpha energy analysis (AEA). 
The leachates were analyzed to determine uranium, ${ }^{137} \mathrm{Cs},{ }^{241} \mathrm{Am}$, total alpha, ${ }^{239,240} \mathrm{Pu}$, and ${ }^{238} \mathrm{Pu} /{ }^{241} \mathrm{Am}$ concentrations by the same analytical measurement techniques as used for the digested solids. Complications in the total alpha analyses of some leach solutions arose because of the high concentrations of dissolved salt. Drying the solutions on radiometric counting planchets left salt deposits, attenuating the emitted alpha particles and decreasing the count rate. The problem evidently was most severe for the $\mathrm{Ce}(\mathrm{IV})$ and $\mathrm{Ag}$ tests. Total alpha results were compared with the sum of the ${ }^{239,240}{ }^{24},{ }^{238} \mathrm{Pu} /{ }^{241} \mathrm{Am}$, and ${ }^{243,244} \mathrm{Cm}$ alpha peaks to identify the severity of the interference (note -- the activity from ${ }^{243,244} \mathrm{Cm}$ is negligible compared with the plutonium and americium activities). In case of the $\mathrm{Ce}$ (IV) and $\mathrm{Ag}$ leachants, the total alpha results were about a factor of 2 lower than the sum of the individual alpha peaks. The $\mathrm{HF}$ and $\mathrm{HCl}$ leachates showed better agreement between the total alpha and summed alpha peak results. To be consistent, the summed alpha peak results were used to provide the total alpha measurement.

Silver present in the ACRES 3 and 4 leachates also posed some problems in the radiochemical analyses. Silver severely quenched the fluorescence in the laser fluorimetric technique used for uranium. As a way to address this problem, conditioned aliquots of leachate in strong hydrochloric acid media were passed through a strong-base macroporous anion-exchange resin column. The uranium was retained and the silver was washed through; the uranium then was eluted with dilute acid and analyzed. Silver also was found to interfere with the AEA for leachates from tests ACRES 3 and 4 because the solutions were reconstituted in $\mathrm{HCl}$ (a non-oxidizing acid) prior to the rare earth fluoride carrier precipitation concentration step used in the analytical procedure. The silver ion formed $\mathrm{AgCl}$ precipitate; the $\mathrm{AgCl}$ solid phase evidently carried much of the TRU activity and prevented it from being analyzed. An alternative method was developed that removed silver from concentrated $\mathrm{HCl}$ solutions by reduction to silver metal using zinc. The supernate, cleared of silver, then was analyzed in the usual manner by rare earth carrier precipitation and counting. 


\subsection{Experimental Results and Discussion}

Experimental observations of the qualitative behavior and radiochemical distributions in the leach testing are presented and interpreted.

\subsection{Qualitative Observations}

The Ce(IV) and silver/persulfate are highly colored leachants whose color (orange and dark brown, respectively) and intensity indicate the persistence of their chemical action. Both reagents retained their color throughout the 4-hour leach contact, though some diminution of intensity was noted for the silver/persulfate. The silver/persulfate reagent also generated gas bubbles continuously both in the reagent bottle and in the leach tests. The nitric/hydrofluoric acid leachate was colorless, but the nitric/hydrochloric acid leachate gained a slight yellow color.

The nitric/hydrofluoric leach test showed no evidence of volatilization of silicon caused by production of $\mathrm{SiF}_{4}$. Such evidence would have been the formation of a slushy silicic acid deposit in the cooler upper vapor-condensing region of the centrifuge cone caused by hydrolysis of the $\mathrm{SiF}_{4}$. Silicic acid deposits have been observed to form in plutonium dissolution from silica(te)-bearing scrap by treatment with boiling nitric/hydrofluoric acid.

Small white particles were observed in the KEACRESID1 sample. These particles were found to be anorthite by XRD. No conspicuous attack or diminution of this material was observed for any leachant, even the nitric/hydrofluoric acid.

Aside from the bubbling in the silver/persulfate tests, no bubbling was noted. No obvious colored fumes were produced.

\subsection{Composition of the Starting Materials}

Radiochemical analyses of the KEACRESID1 starting material (residual solids remaining after acid dissolution of K East area sludge composite) were obtained in other work (Carlson et al. 1998). The concentrations in the KEACRESID1 material derived from that work and quantities in the aliquots prepared for leaching (based on sample weights presented in Table 1) are summarized in Table 2.

Table 2. Radiochemical Concentrations and Quantities in the Starting Materials

\begin{tabular}{|c|c|c|c|c|c|c|}
\hline \multirow{2}{*}{ Solid } & \multicolumn{7}{|c|}{ Concentration in Solid } \\
\cline { 2 - 7 } & $\begin{array}{c}{ }^{30} \mathrm{Cs}, \\
\mu \mathrm{Ci} / \mathrm{g}\end{array}$ & $\begin{array}{c}\mathrm{U}, \\
\mu \mathrm{g} / \mathrm{g}\end{array}$ & $\begin{array}{c}{ }^{239,240} \mathrm{Pu}, \\
\mathrm{nCi} / \mathrm{g}\end{array}$ & $\begin{array}{c}{ }^{241} \mathrm{Am}, \\
\mathrm{nCi} / \mathrm{g}\end{array}$ & $\begin{array}{c}{ }^{28} \mathrm{Pu} /{ }^{241} \mathrm{Am}, \\
\mathrm{nCi} / \mathrm{g}\end{array}$ & $\begin{array}{c}\text { Total Alpha, } \\
\mathrm{nCi} / \mathrm{g}\end{array}$ \\
\hline KEACRESID1 & 3.69 & 120 & 226 & 40 & 77.6 & 303.6 \\
\hline \multirow{2}{*}{ Test } & \multicolumn{7}{|c|}{ Quantity in Test } \\
\cline { 2 - 7 } & $\mu \mathrm{Ci}$ & $\mu \mathrm{g}$ & $\mathrm{nCi}$ & $\mathrm{nCi}$ & $\mathrm{nCi}$ & $\mathrm{nCi}$ \\
\hline ACRES 1 & 0.544 & 17.70 & 33.34 & 5.90 & 11.45 & 44.78 \\
\hline ACRES 2 & 0.552 & 17.95 & 33.81 & 5.98 & 11.61 & 45.42 \\
\hline ACRES 3 & 0.585 & 19.02 & 35.82 & 6.34 & 12.30 & 48.12 \\
\hline ACRES 4 & 0.635 & 20.65 & 38.89 & 6.88 & 13.35 & 52.25 \\
\hline ACRES 5 & 0.566 & 18.40 & 34.65 & 6.13 & 11.90 & 46.54 \\
\hline ACRES 6 & 0.822 & 26.74 & 50.35 & 8.91 & 17.29 & 67.64 \\
\hline ACRES 7 & 0.554 & 18.02 & 33.95 & 6.01 & 11.66 & 45.60 \\
\hline ACRES 8 & 0.618 & 20.09 & 37.83 & 6.70 & 12.99 & 50.82 \\
\hline
\end{tabular}


The ERDF limit for uranium is $0.0026 \mathrm{~g} / \mathrm{mL}$ (which is $0.0013 \mathrm{~g} \mathrm{U} / \mathrm{g}$, assuming a solids bulk density of 2 $\mathrm{g} / \mathrm{mL}$ ). The concentration of uranium in KEACRESID1, $120 \mu \mathrm{g} / \mathrm{g}$ or $0.00012 \mathrm{~g} \mathrm{U} / \mathrm{g}$, is about a factor of 10 below the ERDF criterion. The ${ }^{137} \mathrm{Cs}$ concentration is about a factor of 4 below the ERDF limit of 16 $\mu \mathrm{Ci} / \mathrm{g}(32 \mu \mathrm{Ci} / \mathrm{mL}$ at $2 \mathrm{~g} / \mathrm{mL})$.

The total alpha value for KEACRESID1 is derived as the sum of the ${ }^{239,240} \mathrm{Pu}$ and ${ }^{238} \mathrm{Pu} /{ }^{241} \mathrm{Am}$ AEA measurements. The starting material exceeds the TRU limit of $100 \mathrm{nCi} / \mathrm{g}$ about 3 -fold based on these total alpha results.

The ${ }^{239} \mathrm{Pu}$ and ${ }^{240} \mathrm{Pu}$ each have $29 \mathrm{nCi} / \mathrm{mL}$ ERDF disposal limits. Because ${ }^{239} \mathrm{Pu}$ constitutes about $2 / 3$ of the ${ }^{239,240} \mathrm{Pu}$ activity in $\mathrm{K}$ Basin materials, the ${ }^{239} \mathrm{Pu}$ limit is more restrictive than the ${ }^{240} \mathrm{Pu}$ limit. The ${ }^{239,240} \mathrm{Pu}$ concentration of $226 \mathrm{nCi} / \mathrm{g}$ in KEACRESID1 thus represents about $150 \mathrm{nCi}{ }^{239} \mathrm{Pu} / \mathrm{g}$ or $300 \mathrm{nCi}$ ${ }^{239} \mathrm{Pu} / \mathrm{mL}$, exceeding the ERDF criterion about a factor of 10 . The ${ }^{241} \mathrm{Am}$ concentration of $40 \mathrm{nCi} / \mathrm{g}(80$ $\mathrm{nCi} / \mathrm{mL}$ ) exceeds the $50 \mathrm{nCi} / \mathrm{mL}$ ERDF criterion about 1.6 -fold.

\subsection{Leachate Analyses}

The concentrations of radioelements found in the combined water transfer solutions, leachates, and rinses are presented in Table 3. The concentration data in the replicate tests compare well in light of the small quantities of starting material. As shown in the bottom of Table $3,{ }^{241} \mathrm{Am}$ solution concentrations were obtained by deducting the contribution of ${ }^{238} \mathrm{Pu}$ to the ${ }^{238} \mathrm{Pu} /{ }^{241} \mathrm{Am}$ AEA peak. The measurement uncertainties in the GEA of ${ }^{241} \mathrm{Am}$ ranged from $14 \%$ to $24 \%$ compared with $2 \%$ to $3 \%$ in the AEA. The total alpha results found for the sum of the ${ }^{239,240} \mathrm{Pu},{ }^{238} \mathrm{Pu} /{ }^{241} \mathrm{Am}$, and ${ }^{243,244} \mathrm{Cm}$ activities and the gross alpha measurements are compared in the final two columns. Because of the analytical problems in the gross alpha counting, the summed $\mathrm{Pu} / \mathrm{Am} / \mathrm{Cm}$ data were used to assess total alpha behavior.

Table 3. Radiochemical Concentrations in Combined Test Solutions, Leachates, and Rinses

\begin{tabular}{|c|c|c|c|c|c|c|c|}
\hline \multirow[b]{3}{*}{ Test } & \multicolumn{7}{|c|}{ Leachate Concentrations } \\
\hline & \multirow{2}{*}{$\begin{array}{c}{ }^{137} \mathrm{Cs} \\
\mu \mathrm{Ci} / \mathrm{mL}\end{array}$} & \multirow{2}{*}{$\begin{array}{c}\mathrm{U} \\
\mu \mathrm{g} / \mathrm{mL}\end{array}$} & \multirow{2}{*}{$\begin{array}{l}{ }^{239,240} \mathrm{Pu}, \\
\mathrm{nCi} / \mathrm{mL}\end{array}$} & \multirow{2}{*}{$\begin{array}{c}{ }^{241} \mathrm{Am}, \\
\mathrm{nCi} / \mathrm{mL}^{*}\end{array}$} & \multirow{2}{*}{$\begin{array}{c}{ }^{238} \mathrm{Pu} /{ }^{241} \mathrm{Am} \\
\mathrm{nCi} / \mathrm{mL}\end{array}$} & \multicolumn{2}{|c|}{ Total Alpha, nCi/mL $\mathrm{mL}^{* *}$} \\
\hline & & & & & & $\Sigma \mathrm{Pu} / \mathrm{Am} / \mathrm{Cm}$ & Gross alpha \\
\hline ACRES 1 & 0.0612 & 1.00 & 2.73 & 0.283 & 0.720 & 3.46 & 1.31 \\
\hline ACRES 2 & 0.0418 & 1.23 & 2.34 & 0.255 & 0.629 & 2.98 & 1.46 \\
\hline ACRES 3 & 0.0387 & 1.48 & 4.39 & 0.408 & 1.11 & 5.52 & 2.48 \\
\hline ACRES 4 & 0.0631 & 1.31 & 4.21 & 0.376 & 1.05 & 5.27 & 2.95 \\
\hline ACRES 5 & 0.0430 & 1.28 & 3.61 & 0.532 & 1.11 & 4.74 & 4.23 \\
\hline ACRES 6 & 0.0675 & 2.22 & 5.26 & 0.908 & 1.75 & 7.05 & 6.24 \\
\hline ACRES 7 & 0.0492 & 1.45 & 3.37 & 0.355 & 0.894 & 4.36 & 4.18 \\
\hline ACRES 8 & 0.0566 & 1.26 & 2.78 & 0.342 & 0.787 & 3.59 & 3.44 \\
\hline
\end{tabular}

* To decrease measurement variability, ${ }^{241} \mathrm{Am}$ concentrations were not obtained by GEA but were derived by deducting the contribution of ${ }^{238} \mathrm{Pu}$ to the ${ }^{238} \mathrm{Pu} /{ }^{241} \mathrm{Am}$ AEA peak based on the ${ }^{238} \mathrm{Pu} /{ }^{239,240} \mathrm{Pu}$ activity ratio of 0.16 \pm 0.01 applied to the ${ }^{239,240} \mathrm{Pu}$ AEA peak. The ${ }^{238} \mathrm{Pu} /{ }^{239,240} \mathrm{Pu}$ ratio was taken to be the average of the ratios found in characterization samples from the K East Basin floor and Weasel Pit (Welsh et al. 1996).

** Total alpha results shown are the calculated sums of the ${ }^{239,240} \mathrm{Pu},{ }^{241} \mathrm{Am}$, and ${ }^{243,244} \mathrm{Cm}$ (not presented) activities and the gross alpha activities of the direct-mounted solutions. High dissolved solids produced thick deposits on the counting planchets and caused self-shielding in the total alpha analysis of the direct-mounted $\mathrm{Ce}(\mathrm{IV})$ and $\mathrm{Ag}$ solutions. Therefore, $\Sigma \mathrm{Pu} / \mathrm{Am} / \mathrm{Cm}$ results were used to assess total alpha behavior. 


\subsection{Leach Residue Analyses}

The radiochemical concentrations in the leach residues are given in Table 4. The solids fractional weight losses resulting from the leach treatments also are presented.

Table 4. Radiochemical Concentrations in Test Residues

\begin{tabular}{|c|c|c|c|c|c|c|c|}
\hline \multirow[b]{2}{*}{ Test } & \multicolumn{6}{|c|}{ Concentration } & \multirow{2}{*}{$\begin{array}{c}\text { Fractional } \\
\text { Weight } \\
\text { Loss }\end{array}$} \\
\hline & $\begin{array}{l}{ }^{13 /} \mathrm{Cs}, \\
\mu \mathrm{Ci} / \mathrm{g}\end{array}$ & $\begin{array}{c}\mathrm{U} \\
\mu \mathrm{g} / \mathrm{g}\end{array}$ & $\begin{array}{c}{ }^{239,240} \mathrm{Pu}, \\
\mathrm{nCi} / \mathrm{g}\end{array}$ & $\begin{array}{l}{ }^{241} \overline{A m}, \\
n C i / g *\end{array}$ & $\begin{array}{c}{ }^{238} \mathrm{Pu} /{ }^{241} \mathrm{Am} \\
\mathrm{nCi} / \mathrm{g}\end{array}$ & $\begin{array}{c}\text { Total Alpha, } \\
\text { nCi } / g^{* *}\end{array}$ & \\
\hline ACRES 1 & 1.42 & 19.3 & 47.8 & 17.1 & 24.7 & 72.7 & 0.033 \\
\hline ACRES 2 & 1.46 & 21.4 & $\overline{45.4}$ & 18.0 & 25.3 & 70.8 & 0.043 \\
\hline ACRES 3 & 3.13 & 35.2 & 61.7 & 24.7 & 34.6 & 96.6 & $\overline{0.022}$ \\
\hline ACRES 4 & 3.19 & 32.4 & 59.6 & 23.9 & 33.4 & 93.3 & 0.012 \\
\hline ACRES 5 & 1.49 & $12 . \overline{3}$ & 37.0 & 2.67 & 8.59 & 45.7 & 0.149 \\
\hline ACRES 6 & 1.85 & 10.5 & 33.4 & $\overline{2.43}$ & 7.77 & 41.3 & 0.094 \\
\hline ACRES 7 & 1.59 & 26.6 & 74.0 & 24.0 & 35.8 & 135 & -0.002 \\
\hline ACRES 8 & 0.928 & 17.7 & 45.3 & 14.4 & 21.6 & 67.1 & 0.013 \\
\hline \multicolumn{8}{|c|}{$\begin{array}{l}\text { * To decrease measurement variability, }{ }^{241} \mathrm{Am} \text { concentrations were not obtained by GEA but were } \\
\text { derived by deducting the contribution of }{ }^{238} \mathrm{Pu} \text { to the }{ }^{238} \mathrm{Pu} /{ }^{241} \mathrm{Am} \text { AEA peak based on the } \\
{ }^{238} \mathrm{Pu} /{ }^{239,240} \mathrm{Pu} \text { activity ratio of } 0.16 \pm 0.01 \text { applied to the }{ }^{239,240} \mathrm{Pu} \text { AEA peak. The }{ }^{238} \mathrm{Pu} /{ }^{239,240} \mathrm{Pu} \\
\text { ratio was taken to be the average of the ratios found in characterization samples from the K East } \\
\text { Basin floor and Weasel Pit (Welsh et al. 1996). } \\
\text { Total alpha is the calculated sum of the }{ }^{239,240} \mathrm{Pu},{ }^{241} \mathrm{Am} \text {, and }{ }^{243,244} \mathrm{Cm} \text { (not presented) } \\
\text { activities. High dissolved solids caused self-shielding in the gross alpha analysis of the direct- } \\
\text { mounted digestate, compromising the results. }\end{array}$} \\
\hline
\end{tabular}

The concentration and weight loss data agree well within the duplicate samples, with the exception of ACRES 7 and 8 (nitric/hydrochloric acid leachant). This discrepancy likely originates from difficulties in taking small representative sample aliquots from the visibly heterogeneous KEACRESID1 material (Figure 19 in Carlson et al. 1998). The weight losses caused by leaching are small except, as might be expected, for the nitric/hydrofluoric acid leach tests. This leachant is aggressive towards silicates. The low weight losses for the nitric/hydrochloric acid leach indicate that little iron was removed. This agrees with characterization results (Carlson et al. 1998), which show that KEACRESID1 contains only about 1.3 weight percent iron (it also contains $2.3 \%$ aluminum, $0.7 \%$ calcium, and $36.8 \%$ silicon).

The ${ }^{137} \mathrm{Cs}$ concentration, already below the ERDF limit at about $3.7 \mu \mathrm{Ci} / \mathrm{g}$ in the starting material, decreased a factor of 1.2 to 4 in all tests. Nitric/hydrochloric acid achieved the best decontamination from ${ }^{137} \mathrm{Cs}$. Uranium concentrations in the solids ranged from about 20 to $70 \mu \mathrm{g} / \mathrm{mL}$ (assuming a solids density of $2.0 \mathrm{~g} / \mathrm{mL}$ ). These concentrations are about 40 - to 130 -fold below the ERDF limit of $2,600 \mu \mathrm{g} / \mathrm{mL}$.

The TRU (total alpha) concentrations in the starting material are about 3-times the ERDF criterion whereas the residues from leaching are near or below the ERDF $100 \mathrm{nCi} / \mathrm{g}$ criterion. The lowest TRU concentrations were obtained for the nitric/hydrofluoric acid leachant. The solids remaining from nitric/hydrofluoric acid treatment were about half the ERDF criterion in TRU concentration.

The nitric/hydrofluoric acid leachant is effective for both plutonium and americium contributors to the TRU loading. As shown previously, the initial KEACRESID1 solid is about $300 \mathrm{nCi}^{239} \mathrm{Pu} / \mathrm{mL}$. The concentration in the nitric/hydrofluoric acid-leached residue was about $47 \mathrm{nCi}^{239} \mathrm{Pu} / \mathrm{mL}$, about 1.6-times the ERDF criterion for this isotope. The ${ }^{241} \mathrm{Am}$ concentration decreased about 16 -fold by 
nitric/hydrofluoric acid treatment. This decontamination is strikingly superior to that attained by any other leachant and leaves a residue meeting the $50 \mathrm{nCi}^{241} \mathrm{Am} / \mathrm{mL}$ ERDF criterion by about a factor of 10.

\subsection{Material Balances}

The radiochemical material balances for the leach tests are given in Tables 5 through 10 for ${ }^{137} \mathrm{Cs}, \mathrm{U}$, ${ }^{239,240} \mathrm{Pu},{ }^{241} \mathrm{Am},{ }^{238} \mathrm{Pu} /{ }^{241} \mathrm{Am}$, and total alpha, respectively. The material balances compare the quantities of radiochemicals found in the weighed amounts of starting KEACRESID1 material with the sum of the quantities found in the leach test fractions (solids residue and leachate). The ratios of the "sum found" to the amount in the starting material, expressed as \% recovery, also are given in Tables 5 through 10.

Table 5. Leach Testing Material Balance for ${ }^{137} \mathrm{Cs}$

\begin{tabular}{|c|c|c|c|c|c|}
\hline \multirow{2}{*}{ Test } & \multicolumn{5}{|c|}{${ }^{137} \mathrm{Cs}, \mu \mathrm{Ci}$} \\
\cline { 2 - 6 } & Start & Residue & Leachate & Sum & \% Recovery \\
\hline ACRES 1 & 0.54 & 0.202 & 0.618 & 0.821 & 150.8 \\
\hline ACRES 2 & 0.55 & 0.209 & 0.439 & 0.648 & 117.4 \\
\hline ACRES 3 & 0.58 & 0.485 & 0.387 & 0.872 & 149.1 \\
\hline ACRES 4 & 0.64 & 0.542 & 0.663 & 1.205 & 189.7 \\
\hline ACRES 5 & 0.57 & 0.194 & 0.456 & 0.650 & 114.9 \\
\hline ACRES 6 & 0.82 & 0.373 & 0.709 & 1.082 & 131.6 \\
\hline ACRES 7 & 0.55 & 0.239 & 0.566 & 0.805 & 145.3 \\
\hline ACRES 8 & 0.62 & 0.153 & 0.600 & 0.753 & 122.0 \\
\hline
\end{tabular}

Table 6. Leach Testing Material Balance for Uranium

\begin{tabular}{|c|c|c|c|c|c|}
\hline \multirow{2}{*}{ Test } & \multicolumn{5}{|c|}{ Uranium, $\mu \mathrm{g}$} \\
\cline { 2 - 6 } & Start & Residue & Leachate & Sum & \% Recovery \\
\hline ACRES 1 & 17.70 & 2.75 & 10.10 & 12.85 & 72.6 \\
\hline ACRES 2 & 17.95 & 3.06 & 12.92 & 15.98 & 89.0 \\
\hline ACRES 3 & 19.02 & 5.46 & 14.80 & 20.26 & 106.5 \\
\hline ACRES 4 & 20.65 & 5.50 & 13.70 & 19.20 & 93.0 \\
\hline ACRES 5 & 18.40 & 1.60 & 13.57 & 15.17 & 82.5 \\
\hline ACRES 6 & 26.74 & 2.12 & 23.31 & 25.43 & 95.1 \\
\hline ACRES 7 & 18.02 & 4.00 & 16.62 & 20.62 & 114.4 \\
\hline ACRES 8 & 20.09 & 2.93 & 13.36 & 16.28 & 81.1 \\
\hline
\end{tabular}

Table 7. Leach Testing Material Balance for ${ }^{239,240} \mathrm{Pu}$

\begin{tabular}{|c|c|c|c|c|c|}
\hline \multirow{2}{*}{ Test } & \multicolumn{5}{|c|}{${ }^{239,240} \mathrm{Pu}, \mathrm{nCi}$} \\
\cline { 2 - 6 } & Start & Residue & Leachate & Sum & \% Recovery \\
\hline ACRES 1 & 33.34 & 6.82 & 27.57 & 34.39 & 103.2 \\
\hline ACRES 2 & 33.81 & 6.50 & 24.57 & 31.07 & 91.9 \\
\hline ACRES 3 & 35.82 & 9.56 & 43.90 & 53.46 & 149.3 \\
\hline ACRES 4 & 38.89 & 10.13 & 44.21 & 54.34 & 139.7 \\
\hline ACRES 5 & 34.65 & 4.82 & 38.27 & 43.09 & 124.4 \\
\hline ACRES 6 & 50.35 & 6.74 & 55.23 & 61.97 & 123.1 \\
\hline ACRES 7 & 33.95 & 11.14 & 38.76 & 49.89 & 147.0 \\
\hline ACRES 8 & 37.83 & 7.49 & 29.47 & 36.96 & 97.7 \\
\hline
\end{tabular}


Table 8. Leach Testing Material Balance for ${ }^{241} \mathrm{Am}$

\begin{tabular}{|c|c|c|c|c|c|}
\hline \multirow{2}{*}{ Test } & \multicolumn{5}{|c|}{${ }^{241}$ Am, nCi } \\
\cline { 2 - 6 } & Start & Residue & Leachate & Sum & \% Recovery \\
\hline ACRES 1 & 5.90 & 2.43 & 2.86 & 5.29 & 89.7 \\
\hline ACRES 2 & 5.98 & 2.58 & 2.67 & 5.26 & 87.8 \\
\hline ACRES 3 & 6.34 & 3.83 & 4.08 & 7.91 & 124.7 \\
\hline ACRES 4 & 6.88 & 4.06 & 3.95 & 8.01 & 116.3 \\
\hline ACRES 5 & 6.13 & 0.35 & 5.64 & 5.99 & 97.7 \\
\hline ACRES 6 & 8.91 & 0.49 & 9.54 & 10.03 & 112.5 \\
\hline ACRES 7 & 6.01 & 3.61 & 4.08 & 7.69 & 127.9 \\
\hline ACRES 8 & 6.70 & 2.37 & 3.63 & 6.00 & 89.6 \\
\hline
\end{tabular}

Table 9. Leach Testing Material Balance for ${ }^{238} \mathrm{Pu} /{ }^{241} \mathrm{Am}$

\begin{tabular}{|c|c|c|c|c|c|}
\hline \multirow{2}{*}{ Test } & \multicolumn{5}{|c|}{${ }^{238} \mathrm{Pu} /{ }^{241} \mathrm{Am}, \mathrm{nCi}$} \\
\cline { 2 - 6 } & Start & Residue & Leachate & Sum & \% Recovery \\
\hline ACRES 1 & 11.45 & 3.52 & 7.27 & 10.79 & 94.3 \\
\hline ACRES 2 & 11.61 & 3.62 & 6.60 & 10.23 & 88.1 \\
\hline ACRES 3 & 12.30 & 5.36 & 11.10 & 16.46 & 133.8 \\
\hline ACRES 4 & 13.35 & 5.68 & 11.03 & 16.70 & 125.1 \\
\hline ACRES 5 & 11.90 & 1.12 & 11.77 & 12.89 & 108.3 \\
\hline ACRES 6 & 17.29 & 1.57 & 18.38 & 19.94 & 115.3 \\
\hline ACRES 7 & 11.66 & 5.39 & 10.28 & 15.67 & 134.4 \\
\hline ACRES 8 & 12.99 & 3.57 & 8.34 & 11.91 & 91.7 \\
\hline
\end{tabular}

Table 10. Leach Testing Material Balance for Total Alpha

\begin{tabular}{|c|c|c|c|c|c|}
\hline \multirow{2}{*}{ Test } & \multicolumn{5}{|c|}{ Total Alpha, nCi } \\
\cline { 2 - 6 } & Start & Residue & Leachate & Sum & \% Recovery \\
\hline ACRES 1 & 44.8 & 10.4 & 34.9 & 45.3 & 101.2 \\
\hline ACRES 2 & 45.4 & 10.1 & 31.3 & 41.4 & 91.2 \\
\hline ACRES 3 & 48.1 & 15.0 & 55.2 & 70.2 & 145.8 \\
\hline ACRES 4 & 52.2 & 15.9 & 55.3 & 71.2 & 136.3 \\
\hline ACRES 5 & 46.5 & 5.96 & 50.2 & 56.2 & 120.8 \\
\hline ACRES 6 & 67.6 & 8.33 & 74.0 & 82.4 & 121.8 \\
\hline ACRES 7 & 45.6 & 20.3 & 50.1 & 70.5 & 154.5 \\
\hline ACRES 8 & 50.8 & 11.1 & 38.1 & 49.1 & 96.7 \\
\hline
\end{tabular}

The material balances show the ACRES 3, ACRES 4, and, particularly, the ACRES 7 recoveries to be somewhat high. This likely is an artifact of the difficulties in taking a small representative sample from the visibly heterogeneous KEACRESID1 material.

\subsection{Decontamination Factors}

The solids decontamination factors (DFs), based on dry solids weights, are shown in Table 11. Because relatively little of the solids dissolved, even with nitric/hydrofluoric acid, these DFs represent true leaching and not solubilization caused by dissolution of the matrix. 
Table 11. Decontamination Factors for Solids

\begin{tabular}{|c|c|c|c|c|c|c|}
\hline Test & ${ }^{13} \mathrm{Cs}$ & Uranium & ${ }^{239,240} \mathrm{Pu}$ & ${ }^{241} \mathrm{Am}$ & ${ }^{238} \mathrm{Pu} /{ }^{241} \mathrm{Am}$ & Total Alpha \\
\hline ACRES 1 & 3.9 & 4.5 & 4.9 & 2.1 & 3.0 & 4.2 \\
\hline ACRES 2 & 3.0 & 5.0 & 4.6 & 1.9 & 2.7 & 3.9 \\
\hline ACRES 3 & 1.8 & 3.6 & 5.5 & 2.0 & 3.0 & 4.6 \\
\hline ACRES 4 & 2.2 & 3.4 & 5.3 & 2.0 & 2.9 & 4.4 \\
\hline ACRES 5 & 2.8 & 8.0 & 7.6 & 14.6 & 9.8 & 8.0 \\
\hline ACRES 6 & 2.6 & 10.9 & 8.3 & 18.6 & 11.5 & 9.0 \\
\hline ACRES 7 & 3.4 & 5.2 & 4.5 & 2.1 & 2.9 & 3.5 \\
\hline ACRES 8 & 4.8 & 5.5 & 4.9 & 2.5 & 3.3 & 4.4 \\
\hline
\end{tabular}

The decontamination requirements for $\mathrm{K}$ Basin sludge dissolver residual solids are most pressing, in terms of meeting the ERDF disposal criteria, for the transuranium constituents $\left({ }^{239} \mathrm{Pu},{ }^{241} \mathrm{Am}\right.$, and TRU). These analytes are quantified in the ${ }^{239,240} \mathrm{Pu},{ }^{241} \mathrm{Am},{ }^{238} \mathrm{Pu} /{ }^{241} \mathrm{Am}$, and total alpha results. The DF data in Table 11 show that the nitric/hydrofluoric acid leachant (ACRES 5 and 6) uniformly is the most effective leachant of the four studied for each of these analytes.

The nitric/hydrofluoric acid leachant also provides the highest uranium DFs. The ${ }^{137} \mathrm{Cs} \mathrm{DF}$ afforded by nitric/hydrochloric acid leachant is the best of the four studied although the margin of superiority is small.

\subsection{Dissolution Coefficients}

The fractions of analyte dissolved in the various leach treatments are given in Table 12. The fraction is calculated by dividing the quantity reporting to solution (in the leachate) by the total quantity present in the leach test (leachate plus residue). These quantities, given in Tables 5 through 10 for ${ }^{137} \mathrm{Cs}, \mathrm{U},{ }^{239,240} \mathrm{Pu}$, ${ }^{241} \mathrm{Am},{ }^{238} \mathrm{Pu} /{ }^{241} \mathrm{Am}$, and total alpha, respectively, were used to calculate the dissolution coefficients.

Table 12. Dissolution Coefficients

\begin{tabular}{|c|c|c|c|c|c|c|}
\hline Test & ${ }^{15} \mathrm{Cs}$ & Uranium & ${ }^{239,240} \mathrm{Pu}$ & ${ }^{24} \mathrm{Am}$ & ${ }^{238} \mathrm{Pu}{ }^{241} \mathrm{Am}$ & Total Alpha \\
\hline ACRES 1 & 0.753 & 0.786 & 0.802 & 0.541 & 0.674 & 0.771 \\
\hline ACRES 2 & 0.677 & 0.808 & 0.791 & 0.509 & 0.646 & 0.755 \\
\hline ACRES 3 & 0.444 & 0.731 & 0.821 & 0.515 & 0.674 & 0.787 \\
\hline ACRES 4 & 0.550 & 0.714 & 0.814 & 0.493 & 0.660 & 0.777 \\
\hline ACRES 5 & 0.701 & 0.894 & 0.888 & 0.942 & 0.913 & 0.894 \\
\hline ACRES 6 & 0.655 & 0.917 & 0.891 & 0.951 & 0.921 & 0.899 \\
\hline ACRES 7 & 0.703 & 0.806 & 0.777 & 0.531 & 0.656 & 0.712 \\
\hline ACRES 8 & 0.796 & 0.820 & 0.797 & 0.605 & 0.700 & 0.774 \\
\hline
\end{tabular}




\subsection{References}

Bechtel Hanford, Inc. 1998. Environmental Restoration Disposal Facility Waste Acceptance Criteria, BHI-00139, Rev. 3, Table 3, Richland, Washington.

Bechtold, D.B. 1998. Study of Radionuclide Leaching from the Residues of K Basin Sludge Dissolution, HNF-2917, Numatec Hanford Company, Richland, Washington.

Carlson, C.D., C.H. Delegard, I.E. Burgeson, A.J. Schmidt, and K.L. Silvers. 1998. K Basin Sludge Condition Testing: Nitric Acid Dissolution Testing of K East Area Sludge Composite, Small-and LargeScale Testing. PNNL-12109, Pacific Northwest National Laboratory, Richland, Washington.

Flament, T.A. 1998. Testing Strategy to Support the Development of $K$ Basin Sludge Treatment Process, HNF-2574, Rev.0, Numatec Hanford Company, Richland, Washington.

Schmidt, A. J., K. L. Silvers, P. R. Bredt, C. H. Delegard, E. W. Hoppe, J. M. Tingey, A. H. Zacher, T. L. Welsh, and R. B. Baker. 1999. "Supplementary Information on K-Basin Sludges." HNF-2367, Rev. 0. Fluor Daniel Hanford, Inc., Richland, Washington.

Welsh, T.L., R.B. Baker, D.R. Hansen, G.R. Golcar, and B.J. Makenas. 1996. Analysis of Sludge from Hanford $K$ East Basin Floor and Weasel Pit, WHC-SP-1182, Appendix D, Westinghouse Hanford Company, Richland, Washington. 